Keywords: Waldenstrom macroglobulinemia, Rituximabinduced thrombocytopenia, Ixazomib

Anahtar Sözcükler: Waldenström makroglobülinemisi, Rituksimab ile indüklenen trombositopeni, Iksazomib

\section{Ethics}

Informed Consent: This article does not contain any studies with human participants or animals performed by any of the authors. Informed consent for publication was obtained from the patient.

\section{Authorship Contributions}

Concept: L.Z.; Design: W.M., J.Z., L.Z.; Writing: W.M., L.Z.

Conflict of Interest: No conflict of interest was declared by the authors.

Financial Disclosure: The National Natural Science Foundation of China (81900202, for ZL) and the Fundamental Research Funds for the Central Universities (3332018036, for ZL).

\section{References}

1. Giezen TJ, Mantel-Teeuwisse AK, ten Berg MJ, Straus SM, Leufkens HG, van Solinge WW, Egberts TCG. Rituximab-induced thrombocytopenia: a cohort study. Eur J Haematol 2012;89:256-266.

2. Advani P, Paulus A, Ailawadhi S. Updates in prognostication and treatment of Waldenström's macroglobulinemia. Hematol Oncol Stem Cell Ther 2019:12:179-188.

3. Castillo JJ, Meid K, Gustine JN, Dubeau T, Severns P, Hunter ZR, Yang G, $\mathrm{Xu} \mathrm{L}$, Treon SP. Prospective clinical trial of ixazomib, dexamethasone and rituximab as primary therapy in Waldenström macroglobulinemia. Clin Cancer Res 2018;24:3247-3252.

4. Treon SP, Xu L, Yang G,Zhou Y, Liu X, Cao Y, Sheehy P, Manning RJ, Patterson CJ, Tripsas C, Arcaini L, Pinkus GS, Rodig SJ, Sohani AR, Harris NL, Laramie JM, Skifter DA, Lincoln SE, Hunter ZR. MYD88 L265P somatic mutation in Waldenstrom's macroglobulinemia. N Engl J Med 2012;367:826-833.

5. Dimopoulos MA, Anagnostopoulos A. Waldenström's macroglobulinemia. Best Pract Res Clin Haematol 2005;18:747-765.

6. Vesole DH, Richter J, Biran N, McBride L, Anand P, Huang M, Kumeli AZ, Klippel Z, Iskander K, Siegel DS. Carfilzomib as salvage therapy in Waldenstrom macroglobulinemia: a case series. Leuk Lymphoma 2018;59:259-261.

7. Gertz MA, Rue M, Blood E, Kaminer LS, Vesole DH, Greipp PR. Multicenter phase 2 trial of rituximab for Waldenström macroglobulinemia (WM): an Eastern Cooperative Oncology Group Study (E3A98). Leuk Lymphoma 2004;45:2047-2055.

๑Copyright 2021 by Turkish Society of Hematology

Turkish Journal of Hematology, Published by Galenos Publishing House

\title{
Intravascular Large B-Cell Lymphoma Within the Appendix Presenting as Acute Abdomen: A Challenging Diagnosis for Hematologists
}

\author{
Akut Abdomen ile Prezente olan Apendiksin Intravasküler Büyük B-hücreli Lenfoması: \\ Hematologlar için Zorlu bir Tanı
}

\footnotetext{
(D) Semra Cemre Atalar1, (D) Olga Meltem Akay², (D) Emre Osmanbaşoğlu², (D) Helin Masyan², (D) Orhun Çığ Taşkın³, (D) Burhan Ferhanoğlu²
}

${ }^{1}$ Koç University Faculty of Medicine, Istanbul, Turkey

${ }^{2}$ Koç University Faculty of Medicine, Department of Hematology, Istanbul, Turkey

${ }^{3}$ Koç University Faculty of Medicine, Department of Pathology, İstanbul, Turkey

\section{To the Editor,}

Intravascular large cell lymphoma (ILCL) is a rare subtype of non-Hodgkin lymphoma characterized by the proliferation of lymphoma cells within the lumen of small vessels. The clinical diagnosis of ILCL is challenging due to the absence of obvious lymphadenopathy or a detectable mass [1]. The disease is usually diagnosed postmortem or incidentally in patients with diverse signs and symptoms related to organ dysfunction caused by occlusion of blood vessels [2]. Herein, we report a case of intravascular large B-cell lymphoma (ILBCL) presenting as acute abdomen. The diagnosis was rendered following the histopathologic examination of an appendectomy specimen. To 
our knowledge, this is the first report of ILCL of B-cell origin with appendix involvement.

A 58-year-old male patient was referred to our hospital for investigation of the etiology of his pancytopenia. His laboratory tests demonstrated hemoglobin of $10.9 \mathrm{~g} / \mathrm{dL}$, white blood cell count of $800 / \mu \mathrm{L}$, platelets of $48,000 / \mu \mathrm{L}$, and lactate dehydrogenase of $625 \mathrm{U} / \mathrm{L}$. Bone marrow biopsy revealed dyshematopoiesis, especially in megakaryocytic and granulocytic cell lines, with hypercellular bone marrow including patchy $\mathrm{CD} 20+\mathrm{B}$-cell infiltration in the peritrabecular zone. The intravascular pattern of infiltration was not prominent. Cytogenetic analysis revealed a complex karyotype, and FISH analysis showed trisomy 7 and 21. B-cell lymphoid infiltration in the bone marrow was identified as hematogone-like atypical B-cell proliferation, but further work-up including positron emission tomography/computed tomography (PET/CT) was planned for the differential diagnosis of lymphoproliferative disorders. On the $15^{\text {th }}$ day after his initial admission, the patient suddenly developed abdominal pain. Upon finding rebound tenderness and dilated appendix with a thickened, hyperenhancing wall on CT scan, the patient was sent to the general surgery department for consultation and underwent emergent laparoscopic appendectomy with suspicion of acute appendicitis. In gross examination, the appendix was within normal limits in size and shape.
The histopathological investigation of the appendix yielded a final report of "high-proliferative, neoplastic B-cell infiltration in the vascular structures at the wall and serosa of the appendix" (Figure 1). Histological findings of acute appendicitis were absent. Meanwhile, the results of PET/CT performed prior to surgery were reported as "splenomegaly, hypermetabolic lesion on cecum at right hemipelvis (abscess?), intermediate hypermetabolism at axial skeleton and bilateral humerusfemur" after the operation. In light of these findings, the patient was diagnosed with intravascular large B-cell lymphoma and was given 6 cycles of R-CHOP and intrathecal methotrexate for central nervous system (CNS) prophylaxis. Bone marrow biopsy after 4 cycles of R-CHOP showed normal cytogenetics without any lymphocyte infiltration and complete metabolic remission was detected on interim PET/CT. Follow-up of the patient has been uneventful in the 12 months following the completion of treatment.

Although rare cases of ILBCL of the gastrointestinal tract have been previously described $[3,4,5,6]$, to our knowledge there have been no reports of ILCL of B-cell origin with appendix involvement in the English literature. The only reported case of ILCL involving the appendix was of T-cell origin, described by Malicki et al. [7] in 1999. In 2004, gastrointestinal involvement was reported at a rate of $8 \%$ (3 cases) in a series of 38 patients with ILCL by Ferreri et al. [8]. Since then, there have been limited case reports

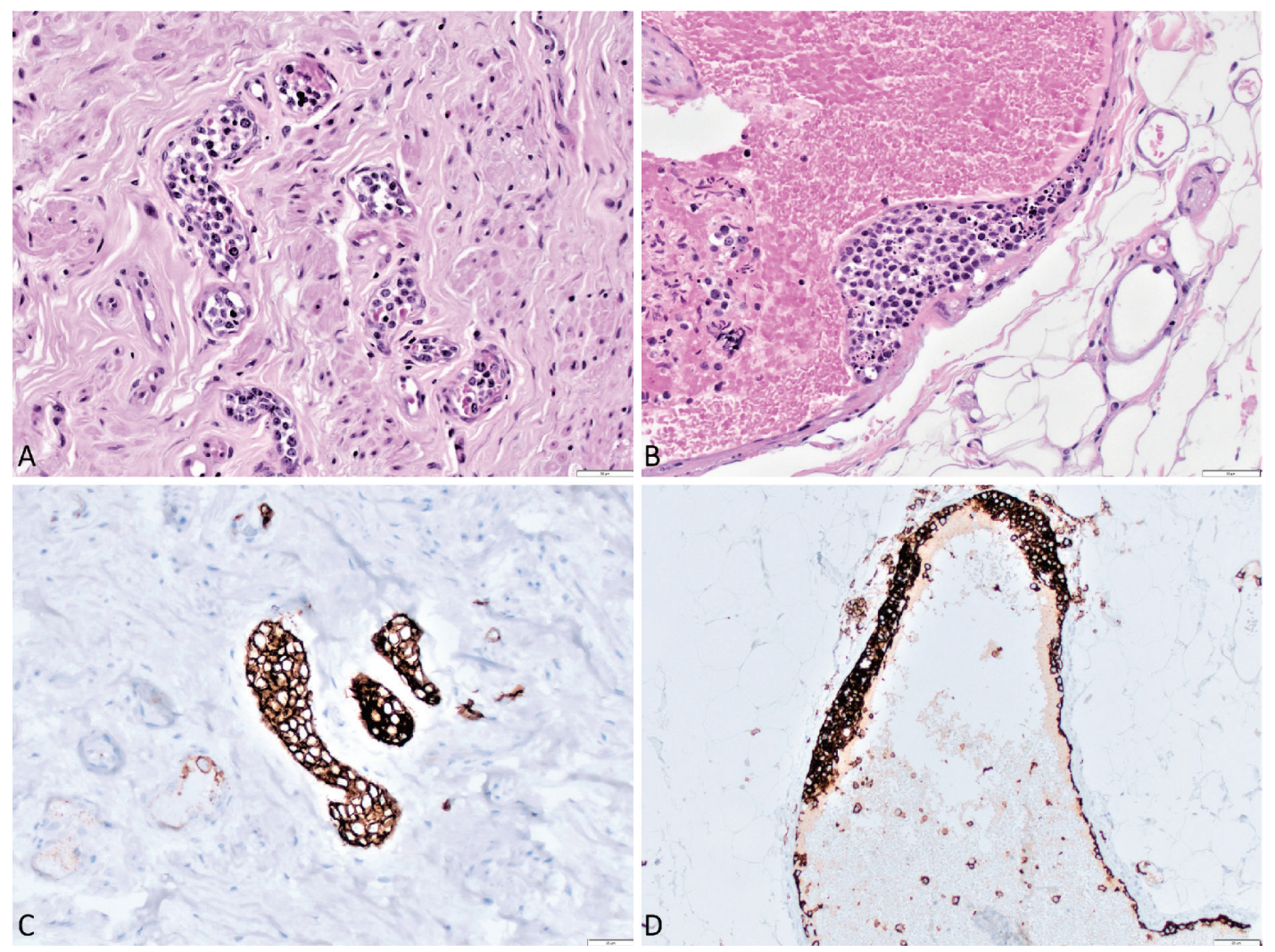

Figure 1. A, B) Infiltration of lymphoid cells in a small and large vessel in the periappendiceal area (H\&E). C, D) CD20 immunohistochemistry, highlighting the B-cell phenotype of the neoplastic cells (CD20). 
in which the gastrointestinal tract was the primary diagnostic site of ILBCL: three in the colon, two in the gastroduodenum, two in the duodenum, two in the ileum, and one in the stomach $[3,5,6]$. Treatment of ILBCL includes both systemic therapy with anthracycline-based regimens and therapy directed at the CNS, since CNS involvement is frequently seen [9]. Clinical outcomes for patients with ILBCL have improved in the rituximab (R) era. In the largest retrospective analysis to date, higher rates of overall and progression-free survival were reported in patients treated with R-chemotherapy compared to chemotherapy alone (66\% and $56 \%$ vs. $46 \%$ and $27 \%$, respectively) [10]. Our patient is the first to present with ILCL of B-cell origin, which was diagnosed as a result of an appendectomy. Early diagnosis in appendectomy and timely initiation of appropriate treatment allowed the successful response in this case. As a take-home message, late-onset acute appendicitis requires careful histological examination to exclude associated systemic diseases such as inflammatory bowel disease, pseudomyxoma, or lymphoma, as in the presented case.

Keywords: Intravascular large B-cell lymphoma, Appendix

Anahtar Sözcükler: Intravasküler büyük B-hücreli lenfoma, Apendiks

\section{Ethics}

Informed Consent: Informed consent has been received from the patient.

\section{Authorship Contributions}

Medical Practices: S.C.A., O.M.A., E.O., H.M., O.Ç.T., B.F.; Concept: O.M.A.; Design: S.C.A., O.M.A.; Data Collection or Processing: S.C.A., O.M.A.; Analysis or Interpretation: S.C.A., O.M.A.; Literature Search: S.C.A., O.M.A.,E.O., H.M.; Writing: S.C.A., O.M.A., O.Ç.T.

Conflict of Interest: No conflict of interest was declared by the authors.

Financial Disclosure: The authors declared that this study received no financial support.

\section{References}

1. Shimada K, Kinoshita T, Naoe T, Nakamura S. Presentation and management of intravascular large B-cell lymphoma. Lancet Oncol 2009;10:895-902.

2. Murase $T$, Nakamura $S$, Tashiro $K$, Suchi $T$, Hiraga J, Hayasaki N, Kimura M, Murakami M, Mizoguchi Y, Suzuki T, Saito H. Malignant histiocytosislike B-cell lymphoma, a distinct pathologic variant of intravascular Iymphomatosis: a report of five cases and review of the literature. $\mathrm{Br} \mathrm{J}$ Haematol 1997;99:656-664.

3. Linnik Y, Rand J, Kaur P, Liu X. Intravascular large B cell lymphoma diagnosed in random duodenal biopsies. A case report and a literature review. Virchows Arch 2017;471:429-431.

4. Lee JH, Lee JK, Ryoo SR, Byun SJ, Han KM, Jung JH, Han IW, Kwon JH, Kim EJ. Intravascular large B-cell lymphoma within duodenal gastrointestinal stromal tumor. Korean J Pancreas Biliary Tract 2016;21:239-243.

5. Kaneyuki D, Komeno $Y$, Yoshimoto $H$, Yoshimura $N$, lihara $K$, Ryu T. Intravascular large B-cell lymphoma mimicking ulcerative colitis with secondary membranoproliferative glomerulonephritis. Intern Med 2016;55:2475-2481.

6. Shimoyama $Y$, Sugimoto $K$, Kotake $M$, Uehara D, Kamide $Y$, Kuribayashi S, Kawamura O, Kusano M, Handa H, Hirato J, Yamada M. Two cases of intravascular lymphoma diagnosed by gastrointestinal endoscopic biopsy. Intern Med 2015;54:3145-3149.

7. Malicki DM, Suh YK, Fuller GN, Shin SS. Angiotropic (intravascular) large cell lymphoma of T-cell phenotype presenting as acute appendicitis in a patient with acquired immunodeficiency syndrome. Arch Pathol Lab Med 1999;123:335-337.

8. Ferreri AJ, Campo E, Seymour JF, Willemze R, Ilariucci F, Ambrosetti A, Zucca E, Rossi G, Lopez-Guillermo A, Pavlosky MA, Geerts ML, Candoni A, Lestani M, Asioli S, Milani M, Piris MA, Pileri S, Facchetti F, Cavalli F, Ponzoni M. Intravascular lymphoma: clinical presentation, natural history, management and prognostic factors in a series of 38 cases, with special emphasis on the 'cutaneous variant'. Br J Haematol 2004;127:173-183.

9. Shimada $K$, Murase $T$, Matsue $K$, Okamoto $M$, Ichikawa $N$, Tsukamoto $N$, Niitsu N, Miwa H, Asaoku H, Kosugi H, Kikuchi A, Matsumoto M, Saburi Y, Masaki Y, Yamamoto K, Yamaguchi M, Nakamura S, Naoe T, Kinoshita T. Central nervous system involvement in intravascular large B-cell lymphoma: a retrospective analysis of 109 patients. Cancer Sci 2010;101:1480-1486.

10. Shimada K, Matsue K, Yamamoto K, Murase T, Ichikawa N, Okamoto M, Niitsu N, Kosugi H, Tsukamoto N, Miwa H, Asaoku H, Kikuchi A, Matsumoto M, Saburi Y, Masaki Y, Yamaguchi M, Nakamura S, Naoe T, Kinoshital T. Retrospective analysis of intravascular large B-cell lymphoma treated with rituximab-containing chemotherapy as reported by the IVL study group in Japan. J Clin Oncol 2008;26:3189-3195.

๑Copyright 2021 by Turkish Society of Hematology

Turkish Journal of Hematology, Published by Galenos Publishing House 